\title{
Information Asymmetry and Foreign Currency Borrowing by Small Firms
}

Martin Brown, Steven Ongena and Pinar Yesin

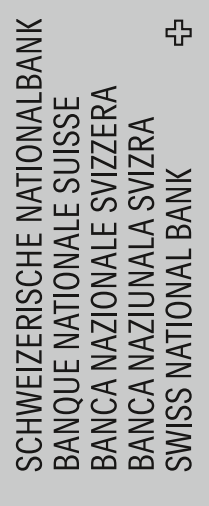

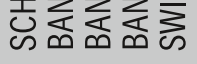


The views expressed in this paper are those of the author(s) and do not necessarily represent those of the Swiss National Bank. Working Papers describe research in progress. Their aim is to elicit comments and to further debate.

\section{Copyright $\odot$}

The Swiss National Bank (SNB) respects all third-party rights, in particular rights relating to works protected by copyright (information or data, wordings and depictions, to the extent that these are of an individual character). SNB publications containing a reference to a copyright ( $\odot$ Swiss National Bank/SNB, Zurich/year, or similar) may, under copyright law, only be used (reproduced, used via the internet, etc.) for non-commercial purposes and provided that the source is mentioned. Their use for commercial purposes is only permitted with the prior express consent of the SNB.

General information and data published without reference to a copyright may be used without mentioning the source.

To the extent that the information and data clearly derive from outside sources, the users of such information and data are obliged to respect any existing copyrights and to obtain the right of use from the relevant outside source themselves.

\section{Limitation of liability}

The SNB accepts no responsibility for any information it provides. Under no circumstances will it accept any liability for losses or damage which may result from the use of such information. This limitation of liability applies, in particular, to the topicality, accuracy, validity and availability of the information.

ISSN 1660-7716 (printed version)

ISSN 1660-7724 (online version)

๑ 2012 by Swiss National Bank, Börsenstrasse 15, P.0. Box, CH-8022 Zurich 


\title{
Information Asymmetry and Foreign Currency Borrowing by Small Firms
}

\author{
Martin Brown*, Steven Ongena**, Pinar Yeşin***
}

April 19, 2012

\begin{abstract}
* University of St Gallen and CentER - Tilburg University, email: martin.brown@ unisg.ch, ** CentER - Tilburg University and CEPR, email: steven.ongena@tilburguniversity.nl, *** Swiss National Bank, email: pinar.yesin@snb.ch. We thank an anonymous referee for the Swiss National Bank Working Paper Series, Raphael Auer, Söhnke Bartram, Henrique Basso, Katalin Bodnar, Geraldo Cerqueiro, Andreas Fischer, Davide Furceri, Luigi Guiso, Werner Hermann, Herman Kamil, Anton Korinek, Marcel Peter, Alexander Popov, Maria Rueda Mauer, Philip Sauré, Linus Siming, Clas Wihlborg and seminar participants at the University of Amsterdam, the Federal Reserve Bank of Boston, the University of Zurich, the Swiss National Bank, as well as participants at the European Finance Association Meeting (Bergen), the SNB-CEPR conference on "Foreign Currency Risk Taking by Financial Institutions, Firms and Households" (Zürich), the Financial Intermediation Research Society Meeting (Prague), the CEPR/Studienzentrum Gerzensee European Summer Symposium in Financial Markets (Gerzensee), the European Economic Association Meetings (Milano), the CREDIT Conference (Venice), ESCE Meetings (Paris), the NBP-SNB Joint Seminar on "Challenges for Central Banks during the Current Global Crisis" and the Tor Vergata Banking and Finance Conference (Rome) for useful comments and discussions. We also thank Simon Wehrmueller for valuable research assistance. Ongena gratefully acknowledges the hospitality of the Swiss National Bank. Any views expressed are those of the authors and do not necessarily reflect those of the Swiss National Bank.
\end{abstract}




\title{
Information Asymmetry and Foreign Currency Borrowing by Small Firms
}

\begin{abstract}
We model the choice of loan currency in a framework which features a trade-off between lower cost of debt and the risk of firm-level distress costs. Under perfect information, if foreign currency funds come at a lower interest rate, all foreign currency earners as well as those local currency earners with high revenues and/or low distress costs choose foreign currency loans. When the banks have imperfect information on the currency and level of firm revenues, even more local earners switch to foreign currency loans, as they do not bear the full cost of the corresponding credit risk. Thus information asymmetry between banks and firms can be a potential driver of "dollarization" in credit markets.
\end{abstract}

Keywords: foreign currency borrowing, competition, banking sector, market structure.

JEL: G21, G30, F34, F37. 


\section{Introduction}

A large proportion of corporations in many countries have been traditionally borrowing in a foreign currency. ${ }^{1}$ More recently and prior to the financial crisis also many retail clients, i.e., households and small firms, in transition and developing countries have taken out foreign currency loans. In countries such as Latvia, Lithuania, Hungary, and Bulgaria, for example, retail clients now hold a similar or larger share of their loans in foreign currency than corporations (European Central Bank (2010)).

What is the key driver of foreign currency borrowing by retail clients in transition and developing countries? These retail loans in foreign currency are popularly believed to be "small men's carry trades", i.e., loans in which households and entrepreneurs seek lower interest rates and take unhedged exchange rate risk upon themselves (see Sorsa, Bakker, Duenwald, Maechler and Tiffin (2007) and Beer, Ongena and Peter (2010)). Yet empirical studies do not always confirm this view. For example, Brown, Ongena and Yeşin (2011) document that foreign currency borrowing by small firms in transition countries is much stronger related to (firm-level) foreign currency revenues than it is to (country-level) interest rate differentials. ${ }^{2}$ Thus "carry-trade behavior" may in fact not be the key driver of foreign currency borrowing.

Recent empirical evidence suggests that foreign banks in transition and developing countries may be behind the surge in foreign currency borrowing by retail clients. In particular, Degryse, Havrylchyk, Jurzyk and Kozak (2012) find that foreign banks that enter via greenfield investment lend more in foreign currency than foreign banks that take-over existing domestic banks. One popular explanation for the role of foreign banks in foreign currency lending is that they are to a large extent financed by their parent-banks in foreign currency. However, recent bank-level evidence by Brown and De Haas (2012) suggests that foreign currency lending to corporate and retail clients in Eastern Europe is unrelated to (foreign currency) wholesale funding.

\footnotetext{
${ }^{1}$ In East Asia, corporate debt is split about equally between foreign and domestic currencies (Allayannis, Brown and Klapper (2003)) while in several Latin American countries the share of foreign currency debt exceeds 20 percent (Galindo, Panizza and Schiantarelli (2003)). Between 20 and 75 percent of all corporate loans in Eastern European countries are denominated in a foreign currency (European Central Bank (2006), p. 39).

${ }^{2}$ Other studies have examined foreign currency borrowing by analyzing aggregate cross-country data (e.g., Luca and Petrova (2008), Rosenberg and Tirpák (2008), Basso, Calvo-Gonzalez and Jurgilas (2011)) or the currency denomination of debt of large firms within a single country (Keloharju and Niskanen (2001), Benavente, Johnson and Morande (2003), Gelos (2003), Kedia and Mozumdar (2003), Cowan, Hansen and Herrera (2005)) or across countries (Rajan and Zingales (1995), Booth, Aivazian, Demirgüç-Kunt and Maksimovic (2001), Allayannis, Brown and Klapper (2003), Cowan (2006), Esho, Sharpe and Webster (2007), Kamil and Sutton (2008), and Kamil (2009)). Clark and Judge (2008) provides a review of the relevant empirical literature.
} 
A further characteristic of foreign banks, which might lead to the surge in foreign currency loans, is that foreign banks may face more information asymmetry than domestic banks which typically have long-established relationships with their clients. This information asymmetry issue may be particularly relevant regarding small firms in transition and developing countries. Banks may not necessarily know the currency in which (small) firms have contracted their sales, and/or the firms' actual or prospective revenue levels, when they evaluate the firms' loan applications.

Though a number of recent theoretical papers have started to model the choice of loan currency in a way that may also be relevant for small firms (Allayannis, Brown and Klapper (2003)), a theoretical framework to understand foreign currency borrowing in retail credit markets where informational asymmetries are acute is still lacking (see also the review in Nagy, Jeffrey and Zettelmeyer (2011)). In this paper we aim to fill this gap in the literature by introducing an information asymmetry between banks and firms in a framework that also features a trade-off between the cost and risk of debt.

Information asymmetries between banks and firms underpin our modern understanding of financial intermediation (Freixas and Rochet (2008)) and the asymmetries may be aggravated in transition and developing countries, where due to the weak corporate legal system it is hard for banks to assess the credibility of available firm-level financial information (Pistor, Raiser and Gelfer (2000), Brown, Jappelli and Pagano (2009)). The costs of information acquisition by banks can be particularly high when dealing with small firms, which are less likely to have audited financial accounts. Depending on bank type, size or ownership and the degree of competition in the banking sector, banks may have difficulties or lack incentives to collect detailed information about sales revenues for example. ${ }^{3}$ In particular, the currency denomination of a firm's current and future sales contracts is often negotiated and a closely guarded secret. ${ }^{4}$ Consequently, "soft" information (about sales revenues and its currency denomination) may be the only type of information that is available, but foreign banks - which are widely present in transition and developing countries may struggle to collect and use it (Stein (2002), Detragiache, Tressel and Gupta (2008)).

Existing models demonstrate that firms' choice of loan currency is affected by the structure of firm revenues, interest rate differentials between local and foreign currency funds, and the distress

\footnotetext{
${ }^{3}$ See for example Dollar and Hallward-Driemeier (2000)). In addition, banks often cannot verify firm sales information through advanced cash management services which are yet to be introduced there, either because banks do not offer these services (e.g., Tsamenyi and Skliarova (2005)) or firms do not demand them (for example, in the survey analyzed in Brown, Ongena and Yeşin (2011), one third of the firms report receiving less than one third of their income through their banks). Banks may also lack information on firm quality, project choice, or managerial effort, for example, incurring monitoring costs (Diamond (1984), Diamond (1991)) or forming relationships with the firms (Sharpe (1990), Rajan (1992), von Thadden (2004), Hauswald and Marquez (2006), or Egli, Ongena and Smith (2006), among others). Also other financiers may face more information asymmetries in transition and developing countries (e.g., Claessens, Djankov and Lang (2000)).

${ }^{4}$ See Friberg and Wilander (2008). Firm risk aversion (Viaene and de Vries (1992)), currency variability (Engel (2006)) and medium of exchange considerations (Rey (2001)) may determine currency choice.
} 
costs of firms facing potential default. ${ }^{5}$ Our theoretical model augments extant work, by featuring not only the trade-off between the risk and the cost of debt, but also a relevant information asymmetry between banks and firms that can have either domestic or foreign currency earnings. Our model first confirms that under perfect information, if there is an interest rate differential in favor of foreign currency funds, then all foreign currency earners will prefer foreign currency loans. In addition, all local currency earners with low distress costs and low debt-income ratios will also choose foreign currency loans. In contrast, local currency earning firms with high distress costs and high debt-income ratios will prefer local currency loans. Then our model shows that if banks cannot identify either the currency or the level of revenues of the firm, more local earners will borrow in foreign currency as the firms do not bear the full cost of the corresponding default risk. The intuition behind this result is the following: As the banks cannot distinguish the "risky" from the "safe" borrowers, they will charge a single interest rate to both types. This interest rate will be lower than the interest rate that prevails when the banks can identify the bad firms. Thus it will be profitable for the risky firms to pool with safe firms and pay a lower risk premium for a foreign currency loan.

Consequently, our model identifies the information asymmetry between lending banks and borrowing firms as a so far overlooked potential driver of "dollarization" in the credit markets. ${ }^{6} \mathrm{We}$

5 If the firm's cash flows are in foreign currency, borrowing in the same foreign currency will provide a straightforward natural hedge (Goswami and Shrikhande (2001)). Mian (1996), Bodnar, Hayt and Marston (1998), Allayannis and Ofek (2001), and Brown (2001), among others, analyze the hedging of foreign currency exposure, using forward contracts and derivatives for example. But many developing country currencies have no forward markets; and even in those that do, there are substantial costs to hedging (Frankel (2004)). And even in developed countries small firms rarely use derivatives to hedge their net currency exposure (Briggs (2004), Børsum and Ødegaard (2005), and O'Connell (2005), among others). As expected therefore, small firms in developing countries not uncommonly default on loans in foreign currency following a deep depreciation of the local currency (Ziaul Hoque (2003)). Static capital structure trade-off theory suggests firms opt for the lowest cost debt, making the interest rate differential, i.e., the deviations from the uncovered interest rate parity (UIP), the second main determinant of the firm's choice of loan currency denomination (Graham and Harvey (2001)).

${ }^{6}$ In Jeanne (2000) financiers face an information asymmetry concerning the effort level of the exporting entrepreneurs. Exporters borrow locally in domestic or foreign currency. But borrowing in a foreign currency serves as a commitment device: The entrepreneurs have a stronger incentive for effort if they have foreign currency debt, because failure to achieve high returns is automatically sanctioned by termination. In Cowan (2006) firms with more foreign income and firms in countries with a higher interest differential (where foreign currency funds are cheaper) will have more foreign debt. Firms that are more financially constrained, i.e., firms that experience a higher risk premium when borrowing from a bank, are more likely to match the denomination of debt to their income streams. These firms would have to borrow at higher costs if they become financially distressed due to the accumulated currency mismatches. If a bank knows a firm is mismatched, it may pass on the corresponding expected default costs. In contrast to Jeanne (2000) where firms only have foreign revenues, in our model firms have domestic or foreign currency earnings. In Jeanne (2000) entrepreneurial effort is unobservable to the financiers; in our model, the currency in which sales are contracted and sales revenues are collected cannot be observed by the bank. Notice that we do not discuss: (1) International taxation issues such as tax loss carry forwards and limitations on foreign tax credits; (2) The possibilities for international income shifting; (3) The differential costs across countries of derivatives to create synthetic local debt; and (4) Clientele effects in issuing public bonds. These issues are clearly important when analyzing the debt structure of large corporations. 
establish the conditions under which all firms will be borrowing in foreign currency (full pooling equilibria), as well as when no foreign currency loans will be offered by banks to firms who cannot prove they have either high or foreign currency income (market failure). The key predictions of our model are consistent with the recent evidence by Degryse, Havrylchyk, Jurzyk and Kozak (2012) who find that foreign banks that enter via greenfield investment, and that may face more information asymmetry than those foreign banks that enter via domestic take-overs, lend more in foreign currency. We leave the more comprehensive testing of our model hypotheses to future empirical research.

The rest of the paper is organized as follows. Our model assumptions are introduced in Section II, followed in Section III by the analysis of the model with perfect information. In Section IV imperfect information is introduced. Section V concludes.

\section{Model Assumptions}

Define $e_{t}$, the exchange rate at time $t$, to equal the amount of local currency per unit of foreign currency, normalized at $t=0$ to $e_{0}=1$. At $t=1$, the local currency either appreciates to $e_{A}<1$, with probability $p$, or it depreciates to $e_{D}>1$, with probability $1-p$. We assume that $p e_{A}+(1-p) e_{D}=1$, so that the expected exchange rate at $t=1$ equals $e_{1}^{*}=1$ and the expected depreciation of the local currency is $\Delta e=\frac{e_{1}^{*}-e_{0}}{e_{0}}=0 .^{7}$

There is a continuum of firms and each firm needs to invest $I=1$ in local currency at $t=0$ to receive any revenues at $t=1$. Firms differ in their revenue currency and revenue level. There are three types of firms, foreign $(F)$, good local $(L G)$ and bad local ( $L B$ ) currency earners. Foreign currency earners have revenue $R^{F}$ in foreign currency, which equals the expected revenue in local currency as the expected exchange rate equals one $\left(e_{1}^{*}=1\right.$, hence $\left.R^{F} e_{1}^{*}=R^{F}\right)$. The other two types of firms have local currency earnings. The good local currency earners have high earnings $R^{L G}$ in local currency and thus a low debt to income ratio. The bad local currency earners have low earnings in local currency, $R^{L B}<R^{L G}$ and thus a higher debt to income ratio.

\footnotetext{
${ }^{7}$ As we assume that the level of firm revenues does not change with the exchange rate, the changes in the exchange rate in our model are assumed to be real.
} 
We abstract from the possibility that foreign currency earners may differ in their income levels and from exchange rate pass-through considerations, as neither issue alters the main insights of our model. ${ }^{8}$

Let all firm types be physically located in the domestic country. Their owners will spend their profits locally, so firms care about their expected payoff in local currency. Firms maximize their expected income and have no other wealth (and are thus limited liable). ${ }^{9}$

There are at least two identical banks that offer loans in both local and foreign currency and that are engaged in Bertrand competition setting prices simultaneously. When they can identify firm type, they charge a net interest rate $r_{k}^{j}$ on a loan in foreign or local currency $k, k \in\{f ; l\}$, to a firm of type $j \in\{F ; L B ; L G\} .{ }^{10}$ Banks have no capacity limits on foreign or local currency funds. We normalize the cost of foreign currency funds to $i_{f}=0$ and set the unit cost of local currency funds to $i_{l}$. We assume that the uncovered interest rate parity (UIP) is not fulfilled, ${ }^{11}$ and that there is an interest rate advantage to foreign currency funding for the bank, i.e., $i_{l}>i_{f}+\Delta e=0$. Extensive empirical research, using a variety of methods, finds that the UIP rarely holds. Furthermore, the literature finds that the deviation from the UIP in emerging markets is systematic in nature and that a significant part of the excess return can be attributed to a risk premium. ${ }^{12}$

For simplicity we assume that interest payments are made upfront at $t=0$, and the loan repayment is made at $t=1 .{ }^{13}$ Firms' earnings are verifiable ex post, so that payments are enforceable if a firm has sufficient earnings.

We assume that the exchange rate volatility is such that bad local currency earners will always default if they take a loan in foreign currency and the local currency depreciates, i.e.,

${ }^{8}$ Under perfect information, all foreign currency earners would take foreign currency loans at the same interest rate independent of their revenue level. With asymmetric information about firm revenues this result also holds for reasonable assumptions on firm-level distress costs, as we show in an earlier version of our model (Brown, Ongena and Yeşin (2009)). See Goldberg and Knetter (1997), for example, on exchange rate pass-through.

${ }^{9}$ While we assume that firms maximize expected income, their payoff is not linear in expected income when we assume distress costs. The assumption of distress costs implies that firms care about income variance, as would be the case if we assumed firms were risk-averse.

${ }^{10}$ Firms in our model receive both their expected income and their loan in a single - though not necessarily the same - currency. Without qualitatively affecting the main hypotheses, our model is readily extendable to include firms that receive their expected income and loans in varying proportions in multiple currencies.

${ }^{11}$ This is a crucial assumption in our model. If the UIP holds, then the local currency earners will not have any incentive to borrow in foreign currency, as they will only bear higher costs either in terms of higher interest rate and/or in terms of prevailing distress costs.

${ }^{12}$ General reviews by Hodrick (1987), Froot and Thaler (1990), Lewis (1995), Engel (1996), for example. For emerging markets, see Francis, Hasan and Hunter (2002) and Alper, Ardic and Fendoglu (2009).

${ }^{13}$ Given our focus, we do not derive the optimality of this debt contract (see Townsend (1979) for example). 
$R^{L B}<e_{D}$. We also assume that all good local currency earners have sufficient revenues to pay back their loan regardless of the exchange rate movements, i.e., $R^{L G}>e_{D}$. Moreover, we assume that foreign currency earners have revenues that will enable them to fully repay a local currency loan even if the local currency appreciates, i.e., $R^{F}>\frac{1}{e_{A}}$.

If firms default on a loan, they face costs of financial distress. For example, defaulters can henceforth find external financing only at penalty costs. In this case, the distress costs $C$ may be proportional to or convex in the default amount (though still homogenous across firms). Alternatively, these costs may involve the private value to its owner of a firm that is lost in bankruptcy (for example, in the case of small and family-owned firms (Froot, Scharfstein and Stein (1993)). ${ }^{14}$ In this case, $C$ will be independent of the default amount, but will be heterogeneous among firms. As the focus of our analysis is the information asymmetry between banks and small firms, we assume that distress costs (in local currency units) differ across firms in each type. Among each type of firm $j \in\{F ; L B ; L G\}$ there is a share $\phi$ with low costs $\underline{C}$ costs and a share $1-\phi$ with high distress costs $\bar{C} .{ }^{15}$

Given the above assumptions, the expected payoff $v_{k}^{j}$ in local currency to a firm of type $j$ taking a loan of type $k$ equals:

$$
v_{k}^{j}=\left\{\begin{array}{ll}
R^{j}-\left(1+r_{k}^{j}\right) & \text { if } j \in\{F ; L G\} \text { or }(j, k)=(L B, l) \\
p\left[R^{L B}-e_{A}\right]-(1-p) C_{i}-r_{f}^{L B} & \text { if }(j, k)=(L B, f)
\end{array} .\right.
$$

\section{Perfect Information Case}

When banks are perfectly informed about the type of each firm, each bank sets six interest rates. For each of the three firm types, $j \in\{L G ; L B ; F\}$, they set two interest rates, depending on whether a foreign or local currency loan is offered.

Proposition 1: Under perfect information, all $F$ and $L G$ firms take foreign currency loans. The equilibrium share of $L B$ firms that choose foreign currency loans is given as:

\footnotetext{
${ }^{14}$ For example, this corresponds to the risk aversion of managers, as in Stulz (1984), or of firms, as in Calvo (2001).

${ }^{15}$ See Brown, Ongena and Yeşin (2009) for a version of the model with a continuous distribution of firms' distress costs. A discrete distribution makes the analysis more elegant, yet does not alter the main intuition that asymmetric information leads to more foreign currency borrowing.
} 
[2]

$$
\delta_{\text {perfect info }}^{L B}=\left\{\begin{array}{ccc} 
& & \\
0 & \text { if } & i_{l}<(1-p) \underline{C} \\
\phi & \text { if } & (1-p) \underline{C} \leq i_{l} \leq(1-p) \bar{C} . \\
& & i_{l}>(1-p) \bar{C}
\end{array}\right.
$$

\section{Proof:}

The expected profits of banks in local currency from each loan type are:

[3]

$$
\Pi_{k}^{j}=\left\{\begin{array}{ll}
r_{k}^{j}-i_{k} & \text { if } j \in\{F ; L G\} \text { or }(j, k)=(L B ; l) \\
p e_{A}+(1-p) R^{L B}-\left(1+i_{f}\right)+r_{f}^{L B} & \text { if }(j, k)=(L B ; f)
\end{array} .\right.
$$

Assuming perfect price competition, the expected profit on each loan type will be zero. Given our assumption that $i_{f}=0$, this leads to the following equilibrium interest rates:

$$
\text { [4] } \quad r_{k}^{j}= \begin{cases}i_{l} & \text { if } k=l \\ 0 & \text { if } j \in\{F ; L G\} \text { and } k=f . \\ (1-p)\left(e_{D}-R^{L B}\right) & \text { if }(j, k)=(L B, f)\end{cases}
$$

Inserting the equilibrium interest rates from [4] into [1], we obtain the following two results. Foreign currency earners ( $F$ types) as well as good local currency earning firms ( $L G$ types) always choose foreign currency loans. And the condition for $L B$ firms to choose a local currency loan is:

[5]

$$
(1-p) C_{i} \geq i_{l}
$$

As a result we obtain the equilibrium share of $L B$ firms that choose foreign currency loans as:

$$
\delta_{\text {perfect info }}^{L B}=\left\{\begin{array}{ccc}
0 & \text { if } & \frac{i_{l}}{1-p}<\underline{C} \\
\phi & \text { if } & \underline{C} \leq \frac{i_{l}}{1-p} \leq \bar{C} \\
1 & \text { if } & \frac{i_{l}}{1-p}>\bar{C}
\end{array}\right.
$$


Proposition 1 shows that under perfect information foreign currency earners ( $F$ types) always choose foreign currency loans. They do so because there is an interest rate advantage to foreign currency loans and they do not run the risk of incurring distress costs when taking such a loan. For the same reason, all good local currency earning firms ( $L G$ types) also choose foreign currency loans. Bad local currency earning firms ( $L B$ types) face a trade-off: If they choose a foreign currency loan they benefit from an interest rate advantage, but they may incur distress costs if the local currency depreciates. As a consequence, if the interest rate differential is low, compared to the minimum distress costs of firms, i.e., when $(1-p) \underline{C}>i_{l}$, we have a "separating" equilibrium in which all $L B$ types, i.e., firms with local currency revenue and high debt to income ratios take local currency loans. If the interest rate differential is high, i.e., when $(1-p) \bar{C}<i_{l}$, we have a "pooling" equilibrium in which all firms take foreign currency loans. For intermediate values of interest rate differentials we have a "partial pooling" equilibrium in which $L B$ firms with low distress costs take foreign currency loans.

\section{Imperfect Information Case}

We now introduce an information asymmetry between banks and firms about the revenues of the firms. Assume that banks can neither verify the currency denomination nor the level of revenues of a firm, i.e., banks cannot distinguish between the three types of firms: $F, L G$, and $L B$ firms. Banks, however, know that a proportion $\lambda \in[0,1]$ of the total firm population are $L B$ firms, and that the remaining proportion $1-\lambda$ are either $F$ or $L G$ firms. ${ }^{16}$ Banks can no longer condition their interest rates on firm types, and thus only offer two rates: $r_{l}$ for local currency loans and $r_{f}$ for foreign currency loans. ${ }^{17}$

In this case, the expected profits of banks in local currency from the two loan types are:

\footnotetext{
16 The bank does not need to separate $F$ from $L G$ firms, as from the previous section we know that these two types never default on any loan, and thus should both receive the same (risk-free) interest rate on either a local or foreign currency loan.

${ }^{17}$ In our model all banks are equally affected by the information asymmetry regardless of the currency in which they lend. Most domestic and foreign banks in Eastern Europe for example offer loans in both local and foreign currency to local firms (see Brown, Kirschenmann and Ongena (2010) and Brown, Ongena and Yeşin (2011)). If financiers lend only in their own currency, existing models predict that: (1) Firms may borrow first in the local and then in the foreign currency, after having exhausted internal funds, if local financiers have better information about the firm than foreign financiers (pecking order hypothesis); (2) Firms with high monitoring costs may borrow more locally in the local currency (Diamond (1984)); and (3) Better firms may borrow in the foreign currency to signal their quality, if foreign currency debt is more expensive (Jeanne (1999)) or entails more regulatory scrutiny hence higher distress costs (Ross (1977)).
} 


$$
\Pi_{k}= \begin{cases}r_{l}-i_{l} & \text { if } k=l \\ \frac{\delta \lambda\left[p e_{A}+(1-p) R^{L B}\right]+(1-\lambda)}{\delta \lambda+(1-\lambda)}-\left(1+i_{f}\right)+r_{f} & \text { if } k=f\end{cases}
$$

where $\delta \in[0,1]$ is the equilibrium share of $L B$ firms taking foreign currency loans. In equilibrium, and with zero expected profit, interest rates must equal:

$$
r_{k}=\left\{\begin{array}{ll}
i_{l} & \text { if } k=l \\
\frac{\delta \lambda}{\delta \lambda+(1-\lambda)}(1-p)\left(e_{D}-R^{L B}\right)>0 & \text { if } k=f
\end{array} .\right.
$$

The interest rate charged on foreign currency loans covers the expected losses due to default on such loans. Under imperfect information, this depends on the share of $L B$ firms taking such loans relative to $F$ and $L G$ firms.

Note that the interest rate that banks charge on foreign currency loans under asymmetric information lies between the rate it charges for such loans under perfect information to $F$ and $L G$ firms, i.e., 0 , and the rate it charges to $L B$ firms, i.e., $r_{f}^{L B}=(1-p)\left(e_{D}-R^{L B}\right)$. In other words, $r_{f} \in\left[0, r_{f}^{L B}\right]$.

Bad local currency earners for which $v_{f}^{L B}\left(r_{f}, C_{i}\right) \geq v_{l}^{L B}\left(i_{l}, C_{i}\right)$ will choose foreign currency loans. From [1] we see that the share of LB firms which will take foreign currency loans will be:

[9] $\delta=\left\{\begin{array}{ccc} & & \\ 0 & \text { if } & i_{l}<r_{f}+(1-p)\left(\underline{C}-e_{D}+R^{L B}\right) \\ \phi & \text { if } & r_{f}+(1-p)\left(\underline{C}-e_{D}+R^{L B}\right) \leq i_{l}<r_{f}+(1-p)\left(\bar{C}-e_{D}+R^{L B}\right) \\ 1 & \text { if } & i_{l} \geq r_{f}+(1-p)\left(\bar{C}-e_{D}+R^{L B}\right)\end{array}\right.$

From [9], we can establish that the lowest interest rate $i_{l}$ at which $L B$ firms start opting for foreign currency loans is $i_{l}=(1-p)\left(\underline{C}+R^{L B}-e_{D}\right)$. We assume from now on that:

$$
\underline{C} \geq e_{D}-R^{L B}>0 \text {. }
$$

Assumption [10] ensures that unless there is a positive interest rate differential to the advantage of foreign currency funds, all $L B$ firms will choose local currency loans. This assumption prevents that some $L B$ firms choose foreign currency loans due to their limited liability even in the absence of an interest rate differential. 
Propositions 2, 3 and 4 summarize how imperfect information changes the feasibility of separating, partial-pooling and full-pooling equilibria in our model. These propositions show that compared to the perfect information case a separating equilibrium exists only for lower interest rate differentials between local and foreign currency. Partial pooling and full pooling equilibria, by contrast, are feasible at lower interest rate differentials than under perfect information.

Proposition 2 (Separating Equilibrium): If $i_{l}<(1-p)\left(\underline{C}-e_{D}+R^{L B}\right)$ a separating equilibrium will emerge.

\section{Proof:}

In a separating equilibrium we have by definition $\delta=0$. From [8] the equilibrium interest rate for foreign currency loans is $r_{f}=0$. From [9] it follows that a separating equilibrium exists if $i_{l}<(1-p)\left(\underline{C}-e_{D}+R^{L B}\right)$

\section{Proposition 3 (Partial Pooling Equilibrium):}

$$
\begin{aligned}
& \text { If } i_{l} \geq(1-p) \underline{C}-\frac{(1-\lambda)}{\phi \lambda+(1-\lambda)}(1-p)\left(e_{D}-R^{L B}\right) \text { and } \\
& i_{l} \leq(1-p) \bar{C}-\frac{(1-\lambda)}{\phi \lambda+(1-\lambda)}(1-p)\left(e_{D}-R^{L B}\right) \text { a partial pooling equilibrium exists in which }
\end{aligned}
$$

only LB firms with low distress costs $\underline{C}$ take foreign currency loans while LB firms with high distress costs $\bar{C}$ take local currency loans.

\section{Proof:}

In a partial pooling equilibrium we have by definition $\delta=\phi$. From [8] the equilibrium interest rate for foreign currency loans is $r_{f}=\frac{\phi \lambda}{\phi \lambda+(1-\lambda)}(1-p)\left(e_{D}-R^{L B}\right)$. From [9] it follows that only LB firms with low distress costs will chose a foreign currency loan if:

$$
\begin{aligned}
& i_{l} \geq(1-p) \underline{C}-\frac{(1-\lambda)}{\phi \lambda+(1-\lambda)}(1-p)\left(e_{D}-R^{L B}\right), \text { and } \\
& i_{l}<(1-p) \bar{C}-\frac{(1-\lambda)}{\phi \lambda+(1-\lambda)}(1-p)\left(e_{D}-R^{L B}\right) \boldsymbol{\square}
\end{aligned}
$$

Proposition 4 shows that full pooling equilibria is feasible under imperfect information starting at a lower interest rate differential than under perfect information. 


\section{Proposition 4 (Full Pooling Equilibrium):}

If $i_{l} \geq(1-p) \bar{C}-(1-\lambda)(1-p)\left(e_{D}+R^{L B}\right)$ a full pooling equilibrium exists in which all LB firms take foreign currency loans.

\section{Proof:}

In a full-pooling equilibrium we have by definition $\delta=1$. From [8] the equilibrium interest rate for foreign currency loans is $r_{f}=\lambda(1-p)\left(e_{D}-R^{L B}\right)$. From [9] it follows that a fullpooling equilibrium exists if $i_{l} \geq(1-p) \bar{C}-(1-\lambda)(1-p)\left(e_{D}-R^{L B}\right)$

Note that in the partial-pooling and full-pooling equilibria described above we have assumed that LG and F firms chose foreign currency loans, which will be the case as long as $r_{f}(\delta) \leq i_{l}$. Assumption [10] ensures that in any equilibrium where $\delta>0$ we have $r_{f}(\delta) \leq i_{l}$.

Figure 1 depicts the equilibria in our model under perfect and imperfect information. The figure shows that under perfect information there always exists either a separating, partial-pooling or full-pooling equilibrium. Under imperfect information two main things change: First, as mentioned above partial-pooling or full-pooling equilibria exist at a larger range of interest rate differentials than under perfect information. This is due to the fact that foreign currency loans to LB firms are not fully pricing the credit risk of these loans due to expected exchange rate depreciations.

The second main difference under imperfect information is that the market for foreign currency loans may collapse. Proposition 5 summarizes the range of parameters for which an equilibrium with lending in foreign currency does not exist.

Proposition 5 (Market Failure Asymmetric Information): Under asymmetric information, there is no equilibrium in which foreign currency loans are extended if one of the following two conditions are met:

$$
\text { [i] }(1-p) \underline{C}-(1-p)\left(e_{D}-R^{L B}\right)<i_{l}<(1-p) \underline{C}-\frac{(1-\lambda)}{\phi \lambda+(1-\lambda)}(1-p)\left(e_{D}-R^{L B}\right)
$$

or

[ii] $(1-p) \bar{C}-\frac{(1-\lambda)}{\phi \lambda+(1-\lambda)}(1-p)\left(e_{D}-R^{L B}\right)<i_{l}<(1-p) \bar{C}-(1-\lambda)(1-p)\left(e_{D}-R^{L B}\right)$

\section{Proof:}

Follows directly from Propositions 2, 3 and 4.

Proposition 5 and Figure 1 show that there are two constellations under which the market for foreign currency loans may collapse with imperfect information. The first constellation is a range of interest rate differentials [i] at which $L B$ firms with low distress consider switching from local 
currency to foreign currency loans if banks charge zero interest rates on foreign currency loans. However, if the $\phi \lambda L B$ firms with low distress costs would switch to foreign currency loans, the zero-profit interest rate on these loans would rise to $\frac{(1-\lambda)}{\phi \lambda+(1-\lambda)}(1-p)\left(e_{D}-R^{L B}\right)$. At that interest rate for foreign currency loans all $L B$ firms will prefer to take local currency loans, and thus there is no equilibrium in which foreign currency loans are offered.

A similar effect lead to market collapse at interest rates in the range [ii], to the extent that these firms would be deterred from taking foreign currency loans. $(1-\phi) \lambda L B$ firms with high distress costs consider switching from local currency to foreign currency loans. In both of these regions the only credit market equilibrium is characterized by all firms taking local currency loans.

\section{Conclusion and Testable Hypotheses}

Motivated by policy concerns about the credit risks resulting from unhedged foreign currency loans, especially in opaque financial environments, we investigate how an information asymmetry between banks and firms in a theoretical framework - that also features the trade-off between the cost and the risk of debt - may determine the currency denomination of bank loans to firms. Banks may not know the currency in which firms have contracted their sales or the level of firm revenues.

Our model shows that foreign currency earners and local currency earners with distress costs that are small vis-à-vis the interest rate differential choose foreign currency loans if the foreign interest rate is lower. With imperfect information for the banks concerning the currency and level of firm revenues, we show that more local currency earners switch to foreign currency loans.

Our model yields several testable hypotheses regarding the firm-level choice of loan denomination. We predict that the likelihood of choosing a foreign currency loan is positively related to the share of income a firm earns in foreign currency. Under the assumptions of our model, all foreign currency earners choose foreign currency loans, so the proportion of foreign currency earners taking foreign currency loans is always at least as high as that of local currency earners.

However, our model shows that not only the currency denomination of a firm's cash flow is important, but also the debt-income ratio of the firm. Among firms with local currency earnings, firms with low debt-income ratios are more likely to take foreign currency loans.

As predicted by the extant literature, the choice of a foreign currency loan should further be negatively related to the firm-level distress costs. The impact of distress costs on loan denomination should be stronger the lower the share of income a firm receives in foreign currency and the lower the revenue.

A key prediction of our model is that the choice of a foreign currency loan by local currency earners may be positively related to the opaqueness of the firm's revenue structure. More local 
currency earners choose foreign currency loans under imperfect information than under perfect information. The impact of information opaqueness is stronger for firms with higher shares of revenue in local currency (our model suggests that imperfect information does not alter the currency choice for firms with foreign currency earnings only). Worsening information opaqueness results in more levered firms (i.e., those with lower cash flow-to-loan ratios) to take foreign currency loans.

At the macroeconomic level, our model predicts that the choice of a foreign currency loan will be positively related to the interest rate advantage on foreign currency funds which is given by nominal interest rate differential between local and foreign currencies minus the expected depreciation of the local currency (which is implicit and equals zero in our model). The impact of the interest rate differential, however, does depend on firm characteristics. The reaction to an increase in the interest rate differential should be stronger for firms with less income in foreign currency.

The choice of a foreign currency loan will further be negatively related to exchange rate volatility. If the local currency is more likely to depreciate and also the larger the depreciation, local currency earners (with low revenues) will be less likely to take a foreign currency loan. Moreover the impact of exchange rate volatility should be stronger for those firms with lower distress costs.

Finally, our model suggests that characteristics of the banking sector or of the legal environment that exacerbate information asymmetries between banks and firms may foster unhedged foreign currency borrowing. 


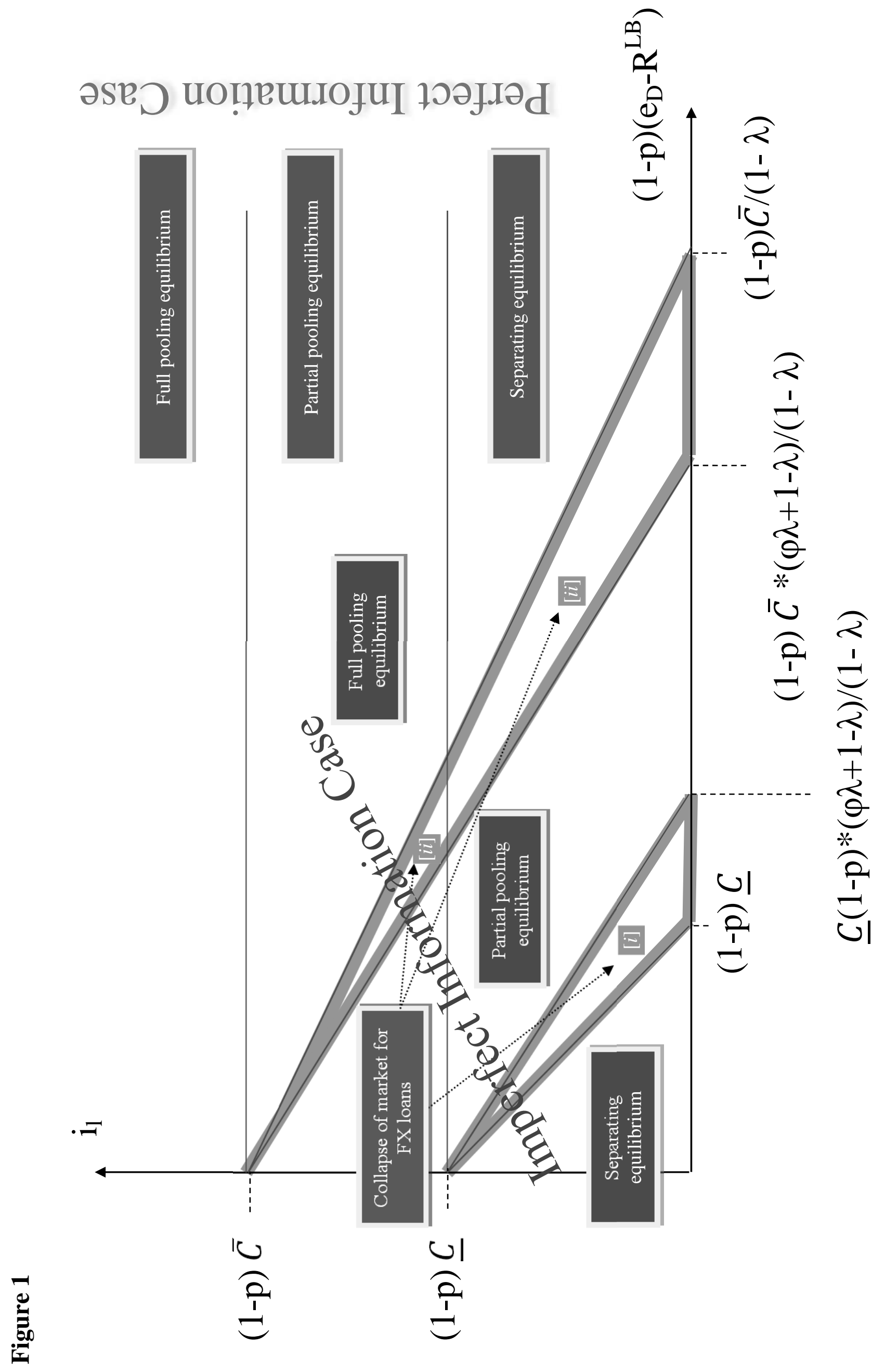




\section{References}

Allayannis, G., G. W. Brown, and L. F. Klapper, 2003, "Capital Structure and Financial Risk: Evidence from Foreign Debt Use in East Asia," Journal of Finance 58, 2667-2709.

Allayannis, G., and E. Ofek, 2001, "Exchange Rate Exposure, Hedging, and the Use of Foreign Currency Derivatives," Journal of International Money and Finance 20, 273-296.

Alper, E., O. P. Ardic, and S. Fendoglu, 2009, "The Economics of the Uncovered Interest Parity Condition for Emerging Markets," Journal of Economic Surveys 23, 115-138.

Basso, H. S., O. Calvo-Gonzalez, and M. Jurgilas, 2011, "Financial Dollarization: The Role of ForeignOwned Banks and Interest Rates," Journal of Banking and Finance 35, 794-806.

Beer, C., S. Ongena, and M. Peter, 2010, "Borrowing in Foreign Currency: Austrian Households as Carry Traders," Journal of Banking and Finance 34, 2198-2211.

Benavente, J. M., C. A. Johnson, and F. G. Morande, 2003, "Debt Composition and Balance Sheet Effects of Exchange Rate Depreciations: A Firm-Level Analysis for Chile," Emerging Markets Review 4, 397-416.

Bodnar, G. M., G. S. Hayt, and R. C. Marston, 1998, "Wharton Survey of Financial Risk Management by US Nonfinancial Firms," Financial Management 27, 70-91.

Booth, L. V., A. Aivazian, A. Demirgüç-Kunt, and V. Maksimovic, 2001, "Capital Structures in Developing Countries," Journal of Finance 56, 87-130.

Børsum, Ø. G., and B. A. Ødegaard, 2005, "Currency Hedging in Norwegian Non-Financial Firms," Norges Bank Economic Bulletin 133-144.

Briggs, P., 2004, "Currency Hedging by Exporters and Importers," Reserve Bank of New Zealand Bulletin 67, 17-27.

Brown, G. W., 2001, "Managing Foreign Exchange Risk with Derivatives," Journal of Financial Economics 60, 401-448.

Brown, M., and R. De Haas, 2012, "Foreign Banks and Foreign Currency Lending in Emerging Europe," Economic Policy 27, 57-98.

Brown, M., T. Jappelli, and M. Pagano, 2009, "Information Sharing and Credit: Firm-Level Evidence from Transition Countries," Journal of Financial Intermediation 18, 151-172.

Brown, M., K. Kirschenmann, and S. Ongena, 2010, Foreign Currency Loans - Demand or Supply Driven?, Swiss National Bank, Zurich.

Brown, M., S. Ongena, and P. Yeşin, 2009, Foreign Currency Borrowing by Small Firms, Swiss National Bank, Zurich.

—, 2011, "Foreign Currency Borrowing by Small Firms in the Transition Economies," Journal of Financial Intermediation 20, 285-302.

Calvo, G. A., 2001, "Capital Markets and the Exchange Rate with Special Reference to the Dollarization Debate in Latin America," Journal of Money. Credit, and Banking 33, 312-334.

Claessens, S., S. D. Djankov, and L. H. P. Lang, 2000, "The Separation of Ownership and Control in East Asian Corporations," Journal of Financial Economics 58, 81-112.

Clark, E., and A. Judge, 2008, "The Determinants of Foreign Currency Hedging: Does Foreign Currency Debt Induce a Bias?," European Financial Management 14, 445-469.

Cowan, K., 2006, Firm Level Determinants of Dollar Debt?, Central Bank of Chile, Santiago.

Cowan, K., E. Hansen, and L. Ó. Herrera, 2005, "Currency Mismatches in Non-Financial Firms in Chile," Journal Economía Chilena - Chilean Economy 8, 57-82.

Degryse, H., O. Havrylchyk, E. Jurzyk, and S. Kozak, 2012, "Foreign Bank Entry, Credit Allocation and Lending Rates in Emerging Markets: Empirical Evidence from Poland," Journal of Banking and Finance Forthcoming.

Detragiache, E., T. Tressel, and P. Gupta, 2008, "Foreign Banks in Poor Countries: Theory and Evidence," Journal of Finance 63, 2123-2160.

Diamond, D. W., 1984, "Financial Intermediation and Delegated Monitoring," Review of Economic Studies 51, 393-414.

—, 1991, "Monitoring and Reputation: the Choice between Bank Loans and Privately Placed Debt," Journal of Political Economy 99, 689-721.

Dollar, D., and M. Hallward-Driemeier, 2000, "Crisis, Adjustment, and Reform in Thailand's Industrial Firms," World Bank Research Observer 15, 1-22.

Egli, D., S. Ongena, and D. C. Smith, 2006, "On the Sequencing of Projects, Reputation Building, and Relationship Finance," Finance Research Letters 3, 23-39. 
Engel, C., 1996, "The Forward Discount Anomaly and the Risk Premium: A Survey of Recent Evidence," Journal of Empirical Finance 3, 123-192.

—, 2006, "Equivalence Results for Optimal Pass-Through, Optimal Indexing to Exchange Rates, and Optimal Choice of Currency for Export Pricing," Journal of the European Economic Association 4, 1249-1260.

Esho, N., I. G. Sharpe, and K. H. Webster, 2007, "Hedging and Choice of Currency Denomination in International Syndicated Loan Markets," Pacific-Basin Finance Journal 15, 195-212.

European Central Bank, 2006, EU Banking Sector Stability, Frankfurt.

—, 2010, European Stability Review, Frankfurt.

Francis, B. B., I. Hasan, and D. M. Hunter, 2002, "Emerging Market Liberalization and the Impact on Uncovered Interest Rate Parity," Journal of International Money and Finance 21, 931-956.

Frankel, J. A., 2004, "Experience of and Lessons from Exchange Rate Regimes in Emerging Economies," in Asian Development Bank, ed., Monetary and Financial Integration in East Asia: The Way Ahead, Palgrave Macmillan Press, New York NY.

Freixas, X., and J. C. Rochet, 2008, Microeconomics of Banking, MIT Press, Cambridge MA.

Friberg, R., and F. Wilander, 2008, "The Currency Denomination of Exports - A Questionnaire Study," Journal of International Economics 75, 54-69.

Froot, K. A., D. S. Scharfstein, and J. C. Stein, 1993, "Risk Management: Coordinating Corporate Investment and Financing Policies," Journal of Finance 48, 1629-1658.

Froot, K. A., and R. H. Thaler, 1990, "Anomalies: Foreign Exchange," Journal of Economic Perspectives 4, 179-192.

Galindo, A., U. Panizza, and F. Schiantarelli, 2003, "Debt Composition and Balance Sheet Effects of Currency Depreciation: A Summary of the Micro Evidence," Emerging Markets Review 4, 330-339.

Gelos, G. R., 2003, "Foreign Currency Debt in Emerging Markets: Firm-Level Evidence from Mexico," Economics Letters 78, 323-327.

Goldberg, P. K., and M. M. Knetter, 1997, "Goods Prices and Exchange Rates: What Have We Learned?," Journal of Economic Literature 35, 1243-1272.

Goswami, G., and M. M. Shrikhande, 2001, "Economic Exposure and Debt Financing Choice," Journal of Multinational Financial Management 11, 39-58.

Graham, J. R., and C. R. Harvey, 2001, "The Theory and Practice of Corporate Finance: Evidence from the Field," Journal of Financial Economics 60, 187-243.

Hauswald, R., and R. Marquez, 2006, "Competition and Strategic Information Acquisition in Credit Markets," Review of Financial Studies 19, 967-1000.

Hodrick, R. J., 1987, The Empirical Evidence on the Efficiency of Forward and Futures Foreign Exchange Markets, Harwood Academic Publishers, Chur.

Jeanne, O., 1999, Foreign Currency Debt and Signaling, International Monetary Fund., Washington DC.

—, 2000, "Foreign Currency Debt and the Global Financial Architecture," European Economic Review 44, 719-727.

Kamil, H., 2009, How Do Exchange Rate Regimes Affect Firms' Incentives to Hedge Currency Risk in Emerging Markets?, International Monetary Fund, Washington DC.

Kamil, H., and B. Sutton, 2008, "Corporate Vulnerability: Have Firms Reduced Their Exposure to Currency Risk," in International Monetary Fund, ed., Regional Economic Outlook: Western Hemisphere, International Monetary Fund, Washington DC.

Kedia, S., and A. Mozumdar, 2003, "Foreign Currency-Denominated Debt: An Empirical Examination," Journal of Business 76, 521-546.

Keloharju, M., and M. Niskanen, 2001, "Why Do Firms Raise Foreign Currency Denominated Debt?," European Financial Management 7, 481-496.

Lewis, K., 1995, "Chapter 37: Puzzles in International Financial Markets," in G. Grossman and K. Rogoff, eds, Handbook of International Economics, Vol. III, Elsevier, North-Holland.

Luca, A., and I. Petrova, 2008, "What Drives Credit Dollarization in Transition Economies?," Journal of Banking and Finance 32, 858-869.

Mian, S. L., 1996, "Evidence on Corporate Hedging Policy," Journal of Financial and Quantitative Analysis 31, 419-439.

Nagy, P. M., S. Jeffrey, and J. Zettelmeyer, 2011, "Addressing Private Sector Currency Mismatches in Emerging Europe," in E. Prasad and M. Kawai, eds, Financial Market Regulation and Reforms in Emerging Markets, Brookings Institution Press, Washington DC.

O'Connell, S., 2005, Currency Game Is Risky for the Smaller Players, Sunday Times.

Pistor, K., M. Raiser, and S. Gelfer, 2000, "Law and Finance in Transition Economies," Economics of Transition 8, 325-368. 
Rajan, R. G., 1992, "Insiders and Outsiders: the Choice between Informed and Arm's-Length Debt," Journal of Finance 47, 1367-1400.

Rajan, R. G., and L. Zingales, 1995, "What Do We Know about Capital Structure? Some Evidence from International Data," Journal of Finance 50, 1421-1460.

Rey, H., 2001, "International Trade and Currency Exchange," Review of Economic Studies 68, 443-464.

Rosenberg, C. B., and M. Tirpák, 2008, Determinants of Foreign Currency Borrowing in the New Member States of the EU, International Monetary Fund, Washington DC.

Ross, S. A., 1977, "The Determination of Financial Structure: the Incentive-Signaling Approach," Bell Journal of Economics 8, 1-30.

Sharpe, S. A., 1990, "Asymmetric Information, Bank Lending and Implicit Contracts: a Stylized Model of Customer Relationships," Journal of Finance 45, 1069-1087.

Sorsa, P., B. B. Bakker, C. Duenwald, A. M. Maechler, and A. Tiffin, 2007, Vulnerabilities in Emerging Southeastern Europe-How Much Cause for Concern?, International Monetary Fund, Washington DC.

Stein, J., 2002, "Information Production and Capital Allocation: Decentralized versus Hierarchical Firms," Journal of Finance 57, 1891-1922.

Stulz, R. M., 1984, "Optimal Hedging Policies," Journal of Financial and Quantitative Analysis 19, 127-140.

Townsend, R. M., 1979, "Optimal Contracts and Competitive Markets with Costly State Verification," Journal of Economic Theory 21, 265-293.

Tsamenyi, M., and D. Skliarova, 2005, "International Cash Management Practices in a Russian Multinational," Managerial Finance 31, 48-64.

Viaene, J.-M., and C. G. de Vries, 1992, "On the Design of Invoicing Practises in International Trade," Open Economies Review 3, 133-142.

von Thadden, E.-L., 2004, "Asymmetric Information, Bank Lending, and Implicit Contracts: the Winner's Curse," Finance Research Letters 1, 11-23.

Ziaul Hoque, M., 2003, "Flawed Public Policies and Industrial Loan Defaults: The Case of Bangladesh," Managerial Finance 29, 98-121. 


\section{Swiss National Bank Working Papers published since 2004:}

2004-1 Samuel Reynard: Financial Market Participation and the Apparent Instability of Money Demand

2004-2 Urs W. Birchler and Diana Hancock: What Does the Yield on Subordinated Bank Debt Measure?

2005-1 Hasan Bakhshi, Hashmat Khan and Barbara Rudolf: The Phillips curve under state-dependent pricing

2005-2 Andreas M. Fischer: On the Inadequacy of Newswire Reports for Empirical Research on Foreign Exchange Interventions

2006-1 Andreas M. Fischer: Measuring Income Elasticity for Swiss Money Demand: What do the Cantons say about Financial Innovation?

2006-2 Charlotte Christiansen and Angelo Ranaldo: Realized Bond-Stock Correlation: Macroeconomic Announcement Effects

2006-3 Martin Brown and Christian Zehnder: Credit Reporting, Relationship Banking, and Loan Repayment

2006-4 Hansjörg Lehmann and Michael Manz: The Exposure of Swiss Banks to Macroeconomic Shocks - an Empirical Investigation

2006-5 Katrin Assenmacher-Wesche and Stefan Gerlach: Money Growth, Output Gaps and Inflation at Low and High Frequency: Spectral Estimates for Switzerland

2006-6 Marlene Amstad and Andreas M. Fischer: Time-Varying Pass-Through from Import Prices to Consumer Prices: Evidence from an Event Study with Real-Time Data

2006-7 Samuel Reynard: Money and the Great Disinflation

2006-8 Urs W. Birchler and Matteo Facchinetti: Can bank supervisors rely on market data? A critical assessment from a Swiss perspective

2006-9 Petra Gerlach-Kristen: A Two-Pillar Phillips Curve for Switzerland

2006-10 Kevin J. Fox and Mathias Zurlinden: On Understanding Sources of Growth and Output Gaps for Switzerland

2006-11 Angelo Ranaldo: Intraday Market Dynamics Around Public Information Arrivals

2007-1 Andreas M. Fischer, Gulzina Isakova and Ulan Termechikov: Do FX traders in Bishkek have similar perceptions to their London colleagues? Survey evidence of market practitioners' views 
2007-2 Ibrahim Chowdhury and Andreas Schabert: Federal Reserve Policy viewed through a Money Supply Lens

2007-3 Angelo Ranaldo: Segmentation and Time-of-Day Patterns in Foreign Exchange Markets

2007-4 Jürg M. Blum: Why ‘Basel II’ May Need a Leverage Ratio Restriction

2007-5 Samuel Reynard: Maintaining Low Inflation: Money, Interest Rates, and Policy Stance

2007-6 Rina Rosenblatt-Wisch: Loss Aversion in Aggregate Macroeconomic Time Series

2007-7 Martin Brown, Maria Rueda Maurer, Tamara Pak and Nurlanbek Tynaev: Banking Sector Reform and Interest Rates in Transition Economies: Bank-Level Evidence from Kyrgyzstan

2007-8 Hans-Jürg Büttler: An Orthogonal Polynomial Approach to Estimate the Term Structure of Interest Rates

2007-9 Raphael Auer: The Colonial Origins Of Comparative Development: Comment. A Solution to the Settler Mortality Debate

2007-10 Franziska Bignasca and Enzo Rossi: Applying the Hirose-Kamada filter to Swiss data: Output gap and exchange rate pass-through estimates

2007-11 Angelo Ranaldo and Enzo Rossi: The reaction of asset markets to Swiss National Bank communication

2007-12 Lukas Burkhard and Andreas M. Fischer: Communicating Policy Options at the Zero Bound

2007-13 Katrin Assenmacher-Wesche, Stefan Gerlach, and Toshitaka Sekine: Monetary Factors and Inflation in Japan

2007-14 Jean-Marc Natal and Nicolas Stoffels: Globalization, markups and the natural rate of interest

2007-15 Martin Brown, Tullio Jappelli and Marco Pagano: Information Sharing and Credit: Firm-Level Evidence from Transition Countries

2007-16 Andreas M. Fischer, Matthias Lutz and Manuel Wälti: Who Prices Locally? Survey Evidence of Swiss Exporters

2007-17 Angelo Ranaldo and Paul Söderlind: Safe Haven Currencies 
2008-1 Martin Brown and Christian Zehnder: The Emergence of Information Sharing in Credit Markets

2008-2 Yvan Lengwiler and Carlos Lenz: Intelligible Factors for the Yield Curve

2008-3 Katrin Assenmacher-Wesche and M. Hashem Pesaran: Forecasting the Swiss Economy Using VECX* Models: An Exercise in Forecast Combination Across Models and Observation Windows

2008-4 Maria Clara Rueda Maurer: Foreign bank entry, institutional development and credit access: firm-level evidence from 22 transition countries

2008-5 Marlene Amstad and Andreas M. Fischer: Are Weekly Inflation Forecasts Informative?

2008-6 Raphael Auer and Thomas Chaney: Cost Pass Through in a Competitive Model of Pricing-to-Market

2008-7 Martin Brown, Armin Falk and Ernst Fehr: Competition and Relational Contracts: The Role of Unemployment as a Disciplinary Device

2008-8 Raphael Auer: The Colonial and Geographic Origins of Comparative Development

2008-9 Andreas M. Fischer and Angelo Ranaldo: Does FOMC News Increase Global FX Trading?

2008-10 Charlotte Christiansen and Angelo Ranaldo: Extreme Coexceedances in New EU Member States' Stock Markets

2008-11 Barbara Rudolf and Mathias Zurlinden: Measuring capital stocks and capital services in Switzerland

2008-12 Philip Sauré: How to Use Industrial Policy to Sustain Trade Agreements

2008-13 Thomas Bolli and Mathias Zurlinden: Measuring growth of labour quality and the quality-adjusted unemployment rate in Switzerland

2008-14 Samuel Reynard: What Drives the Swiss Franc?

2008-15 Daniel Kaufmann: Price-Setting Behaviour in Switzerland - Evidence from CPI Micro Data

2008-16 Katrin Assenmacher-Wesche and Stefan Gerlach: Financial Structure and the Impact of Monetary Policy on Asset Prices

2008-17 Ernst Fehr, Martin Brown and Christian Zehnder: On Reputation: A Microfoundation of Contract Enforcement and Price Rigidity 
2008-18 Raphael Auer and Andreas M. Fischer: The Effect of Low-Wage Import Competition on U.S. Inflationary Pressure

2008-19 Christian Beer, Steven Ongena and Marcel Peter: Borrowing in Foreign Currency: Austrian Households as Carry Traders

2009-1 Thomas Bolli and Mathias Zurlinden: Measurement of labor quality growth caused by unobservable characteristics

2009-2 Martin Brown, Steven Ongena and Pinar Yeșin: Foreign Currency Borrowing by Small Firms

2009-3 Matteo Bonato, Massimiliano Caporin and Angelo Ranaldo: Forecasting realized (co)variances with a block structure Wishart autoregressive model

2009-4 Paul Söderlind: Inflation Risk Premia and Survey Evidence on Macroeconomic Uncertainty

2009-5 Christian Hott: Explaining House Price Fluctuations

2009-6 Sarah M. Lein and Eva Köberl: Capacity Utilisation, Constraints and Price Adjustments under the Microscope

2009-7 Philipp Haene and Andy Sturm: Optimal Central Counterparty Risk Management

2009-8 Christian Hott: Banks and Real Estate Prices

2009-9 Terhi Jokipii and Alistair Milne: Bank Capital Buffer and Risk Adjustment Decisions

2009-10 Philip Sauré: Bounded Love of Variety and Patterns of Trade

2009-11 Nicole Allenspach: Banking and Transparency: Is More Information Always Better?

2009-12 Philip Sauré and Hosny Zoabi: Effects of Trade on Female Labor Force Participation

2009-13 Barbara Rudolf and Mathias Zurlinden: Productivity and economic growth in Switzerland 1991-2005

2009-14 Sébastien Kraenzlin and Martin Schlegel: Bidding Behavior in the SNB's Repo Auctions

2009-15 Martin Schlegel and Sébastien Kraenzlin: Demand for Reserves and the Central Bank's Management of Interest Rates

2009-16 Carlos Lenz and Marcel Savioz: Monetary determinants of the Swiss franc 
2010-1 Charlotte Christiansen, Angelo Ranaldo and Paul Söderlind: The Time-Varying Systematic Risk of Carry Trade Strategies

2010-2 Daniel Kaufmann: The Timing of Price Changes and the Role of Heterogeneity

2010-3 Loriano Mancini, Angelo Ranaldo and Jan Wrampelmeyer: Liquidity in the Foreign Exchange Market: Measurement, Commonality, and Risk Premiums

2010-4 Samuel Reynard and Andreas Schabert: Modeling Monetary Policy

2010-5 Pierre Monnin and Terhi Jokipii: The Impact of Banking Sector Stability on the Real Economy

2010-6 Sébastien Kraenzlin and Thomas Nellen: Daytime is money

2010-7 Philip Sauré: Overreporting 0il Reserves

2010-8 Elizabeth Steiner: Estimating a stock-flow model for the Swiss housing market

2010-9 Martin Brown, Steven Ongena, Alexander Popov, and Pinar Yeșin: Who Needs Credit and Who Gets Credit in Eastern Europe?

2010-10 Jean-Pierre Danthine and André Kurmann: The Business Cycle Implications of Reciprocity in Labor Relations

2010-11 Thomas Nitschka: Momentum in stock market returns: Implications for risk premia on foreign currencies

2010-12 Petra Gerlach-Kristen and Barbara Rudolf: Macroeconomic and interest rate volatility under alternative monetary operating procedures

2010-13 Raphael Auer: Consumer Heterogeneity and the Impact of Trade Liberalization: How Representative is the Representative Agent Framework?

2010-14 Tommaso Mancini Griffoli and Angelo Ranaldo: Limits to arbitrage during the crisis: funding liquidity constraints and covered interest parity

2010-15 Jean-Marc Natal: Monetary Policy Response to Oil Price Shocks

2010-16 Kathrin Degen and Andreas M. Fischer: Immigration and Swiss House Prices

2010-17 Andreas M. Fischer: Immigration and large banknotes

2010-18 Raphael Auer: Are Imports from Rich Nations Deskilling Emerging Economies? Human Capital and the Dynamic Effects of Trade 
2010-19 Jean-Pierre Danthine and John B. Donaldson: Executive Compensation: A General Equilibrium Perspective

2011-1 Thorsten Beck and Martin Brown: Which Households Use Banks? Evidence from the Transition Economies

2011-2 Martin Brown, Karolin Kirschenmann and Steven Ongena: Foreign Currency Loans Demand or Supply Driven?

2011-3 Victoria Galsband and Thomas Nitschka: Foreign currency returns and systematic risks

2011-4 Francis Breedon and Angelo Ranaldo: Intraday patterns in FX returns and order flow

2011-5 Basil Guggenheim, Sébastien Kraenzlin and Silvio Schumacher: Exploring an uncharted market: Evidence on the unsecured Swiss franc money market

2011-6 Pamela Hall: Is there any evidence of a Greenspan put?

2011-7 Daniel Kaufmann and Sarah Lein: Sectoral Inflation Dynamics, Idiosyncratic Shocks and Monetary Policy

2011-8 Iva Cecchin: Mortgage Rate Pass-Through in Switzerland

2011-9 Raphael A. Auer, Kathrin Degen and Andreas M. Fischer: Low-Wage Import Competition, Inflationary Pressure, and Industry Dynamics in Europe

2011-10 Raphael A. Auer and Philip Sauré: Spatial Competition in Quality, Demand-Induced Innovation, and Schumpeterian Growth

2011-11 Massimiliano Caporin , Angelo Ranaldo and Paolo Santucci de Magistris: On the Predictability of Stock Prices: a Case for High and Low Prices

2011-12 Jürg Mägerle and Thomas Nellen: Interoperability between central counterparties

2011-13 Sylvia Kaufmann: K-state switching models with endogenous transition distributions

2011-14 Sébastien Kraenzlin and Benedikt von Scarpatetti: Bargaining Power in the Repo Market

2012-01 Raphael A. Auer: Exchange Rate Pass-Through, Domestic Competition, and Inflation: Evidence from the 2005/08 Revaluation of the Renminbi

2012-02 Signe Krogstrup, Samuel Reynard and Barbara Sutter: Liquidity Effects of Quantitative Easing on Long-Term Interest Rates 
2012-03 Matteo Bonato, Massimiliano Caporin and Angelo Ranaldo: Risk spillovers in international equity portfolios

2012-04 Thomas Nitschka: Banking sectors' international interconnectedness: Implications for consumption risk sharing in Europe

2012-05 Martin Brown, Steven Ongena and Pinar Yeşin: Information Asymmetry and Foreign Currency Borrowing by Small Firms 
Swiss National Bank Working Papers are also available at www.snb.ch, section Publications/Research Subscriptions or individual issues can be ordered at Swiss National Bank, Fraumünsterstrasse 8, CH-8022 Zurich, fax+41 4463181 14, E-mail library@snb.ch 